\title{
MOUTH BREATHING CHILDREN HAVE CEPHALOMETRIC PATTERNS SIMILAR TO THOSE OF ADULT PATIENTS WITH OBSTRUCTIVE SLEEP APNEA SYNDROME
}

\author{
Maria Ligia Juliano', Marco Antonio Cardoso Machado², Luciane Bizari Coin de Carvalho3, \\ Lucila Bizari Fernandes do Prado 4 , Gilmar Fernandes do Prado 5
}

\begin{abstract}
Objective: To determine whether mouth breathing children present the same cephalometric patterns as patients with obstructive sleep apnea syndrome (OSAS). Method: Cephalometric variables were traced and measured on vertical lateral cephalometric radiographs. The cephalometric measurements of 52 mouth and 90 nose breathing children were compared with apneic patients. The children had not undergone adenoidectomy or tonsillectomy and had not had or were not receiving orthodontic or orthopedic treatment. Results: Mouth breathing children showed same cephalometric pattern observed in patients with OSAS: a tendency to have a retruded mandible $(p=0.05)$, along with greater inclination of the mandibular and occlusal planes $(p<0.01)$ and a tendency to have greater inclination of the upper incisors $(p=0.08)$. The nasopharyngeal and posterior airway spaces were greatly reduced in mouth breathing children, as observed in patients with apnea $(p<0.01)$. Conclusion: Mouth breathing children present abnormal cephalometric parameters and their craniofacial morphology resembles that of patients with OSAS.
\end{abstract}

KEY WORDS: cephalometry, mouth breathing, obstructive sleep apnea.

\section{Crianças respiradoras bucais apresentam padrão cefalométrico semelhante àquele observado em pacientes adultos com síndrome da apnéia obstrutiva do sono}

Resumo - Objetivo: Determinar se crianças respiradoras bucais apresentam o mesmo padrão cefalométrico que os pacientes que tem sindrome da apnéia obstrutiva do sono (SAOS). Método: Foram traçadas radiografias laterais verticais da cabeça para a mensuração das variáveis cefalométricas. As medidas cefalométricas de 52 crianças respiradoras bucais e de 90 crianças respiradoras nasais foram comparadas à de pacientes com apnéia. Foram excluídas as crianças que haviam sido submetidas à cirurgia de remoção de amídalas ou adenóides, ou que haviam recebido tratamento ortodôntico prévio ou em andamento. Resultados: As crianças respiradoras bucais apresentaram o mesmo padrão cefalométrico observado em pacientes com SAOS: tendência a ter retrusão de mandíbula $(p=0,05)$, assim como uma maior inclinação dos planos mandibular e oclusal $(p<0,01) e$ tendência a ter maior inclinação dos incisivos superiores $(p=0,08)$. $O$ espaço da nasofaringe e o espaço aéreo posterior se apresentaram muito diminuídos nas crianças respiradoras bucais, como é observado em pacientes com SAOS $(p<0,01)$. Conclusão: Crianças respiradoras bucais apresentam padrão cefalométrico alterado e sua morfologia craniofacial é semelhante àquela observada em pacientes com SAOS.

PALAVRAS-CHAVE: cefalometria, respiração bucal, apnéia obstrutiva do sono.

Obstructive sleep apnea syndrome (OSAS) in adults is characterized by repeated episodes of cessation of breathing during sleep. These episodes result from obstruction of the upper airways, which collapse at different levels ranging from the nasal fossae to the lower por- tion of the hypopharynx'. The nocturnal symptoms include snoring, restless sleep, frequent arousals, apneas and excessive sweating. The daytime problems are morning headache, excessive daytime sleepiness and development of physical complications that include systemic hy-

Neuro-Sono, Hospital São Paulo Sleep Laboratory, Department of Neurology and Department of Medicine, Federal University of São Paulo, São Paulo SP, Brazil: 'PhD, DDS, Orthodontist, Neuro-Sono Researcher; ${ }^{2} \mathrm{PhD}$, DDS, Neuro-Sono Researcher; ${ }^{3} \mathrm{PhD}$, Neuro-Sono Researcher; ${ }^{4} \mathrm{MD}$, PhD, Director of Hospital São Paulo Sleep Laboratory; ${ }^{5} \mathrm{MD}$, PhD, Director of Neuro-Sono.

Received 19 June 2009, received in final form 30 June 2009. Accepted 3 July 2009.

Dra. Maria Ligia Juliano - Neurologia EPM / UNIFESP - Rua Botucatu 740 - 04023-900 São Paulo SP -Brasil. E-mail: lijuliano@ig.com.br 
pertension and cardiac arrhythmias ${ }^{2}$. A reduced nasopharyngeal air space favors occurrences of OSAS. The size of this space is affected by craniofacial morphology ${ }^{3}$, and is influenced by heredity ${ }^{4}$. Patients with OSAS show similar morphological characteristics, such as cervical hyperextension, an abnormal relationship between the maxilla and mandible, abnormalities in the dental arches, micrognathia and retrognathia ${ }^{3}$. The association between craniofacial anomalies and respiratory sleep disorders such as snoring has been confirmed in several studies ${ }^{5-7}$. The pathophysiology of childhood OSAS is still poorly understood. Although adenotonsillar hypertrophy is certainly the main factor contributing to OSAS ${ }^{8}$, other factors such as craniofacial anomalies ${ }^{5}$ or genetic factors ${ }^{9}$ are believed to be implicated in its development. Children with adenoidal hypertrophy present nasal obstruction with consequent chronic mouth breathing ${ }^{10}$. Unlike adults, few children with OSAS report excessive daytime sleepiness". Instead, symptoms like behavioral changes, cognitive abnormalities, concentration difficulties and learning difficulties generally occur ${ }^{8,2}$. Facial growth abnormalities are observed among children with OSAS ${ }^{7}$ and among mouth breathing children ${ }^{13,14}$, in addition to poor growth due to increased energy expenditure during sleep ${ }^{15}$, hyperactivity and antisocial behavior, and symptoms of depression ${ }^{16}$, cognitive difficulty ${ }^{17,18}$ and motor dysfunction ${ }^{19}$.

Children with abnormal craniofacial patterns show a predisposition towards some types of respiratory sleep disorder, as do children with tonsillar and adenoid hypertrophy. These factors favor the development of mouth breathing ${ }^{10,20}$. Mouth breathing during the growth phase is an important factor responsible for a sequence of events that commonly result in growth changes and abnormalities of cranial and maxillomandibular development ${ }^{14}$. An association between mouth breathing during sleep and increased propensity for upper airway collapse has been well documented ${ }^{20}$. Moreover, there seems to be a correlation between the anatomical shape of the upper airways and abnormalities in craniofacial morphology among mouth breathing individuals ${ }^{21}$. Mouth breathing can induce dental malocclusion ${ }^{22}$, which generally leads to increased anterior facial height, a narrow and deep palate, increased lower facial height ${ }^{23}$, open biting and a tendency towards cross-biting ${ }^{14,22}$, along with occurrences of hearing loss ${ }^{24}$. Cephalometry is useful as a screening test for anatomical abnormalities among patients with OSAS ${ }^{6,7}$. Measurements assessing the anteroposterior position of the maxilla and mandible, inclination of the mandibular and occlusal planes, position of the anterior teeth, dimensions of the nasopharyngeal and posterior air spaces and characteristics of the hyoid bone are the ones most associated with OSAS ${ }^{6,25,26}$. The pattern of these measurements presented by OSAS patients is referred to as apneic pattern ${ }^{3}$.
Thus, the objective of the present study was to determine whether mouth breathing children present the same cephalometric pattern as apneic patients.

\section{METHOD}

\section{Participants}

This study was conducted on 142 children aged 7 to 14 years, including 52 mouth breathing children ( 27 boys) and 90 nose breathing children ( 58 boys). They were recruited from two Pastoral Community Centers in the district of Jardim Colonial, city of São Paulo, Brazil. The children were transported to the Papaiz Associates Dental Radiology Institute, São Paulo, for vertical lateral cephalometric radiographs to be produced. One child did not appear on the day of the examination. Children who had undergone surgical treatment of the oral cavity and/or structures relating to the nasopharyngeal air space, such as tonsillectomy, adenoidectomy or adenotonsillectomy were excluded from the study. Children who had previously had or were currently receiving orthodontic or facial orthopedic treatment were also excluded.

The study was approved by the Ethics Committee of the Federal University of São Paulo (UNIFESP) (case number 0896/03). After receiving information about the objectives of the study, the parents of the children or other adults responsible for them signed the consent form and an authorization for the children to be transported to the Radiology Institute for cephalometric radiography.

\section{Assessment}

To be classified as mouth breathers, the children needed to fulfill all of the following clinical criteria: their parents reported that they were breathing through the mouth, sleeping with the mouth opened and dribbling on the pillow three times a week or more. Children were classified as nose breathers when their parents did not report any of the above complaints. We only took in account loud and continuous snoring as complementary information for classifying children as mouth breathers, because this kind of information is variable and subject to individual sensitivity and the degree of attention paid towards children. All of the children underwent an orthodontic evaluation (data not shown in this study) and lateral teleradiography to obtain cephalometric tracings.

Lateral cephalometric radiographs - Lateral cephalometric radiographs (Fig 1) were obtained with the children sitting on a chair in an upright position, with the teeth in natural occlusion. A cephalostat was used to keep the subject's head in such a position that the Frankfurt plane was parallel to the floor. Before radiography, the children used a mouth rinse and swallowed $10 \mathrm{ml}$ barium sulfate to allow structures such as the tongue, soft palate, epiglottis and posterior region of the pharynx to be seen. The EMIC MKT $100 \mathrm{X}$-ray apparatus was used, and a distance of $152 \mathrm{~cm}$ was maintained between the $X$-ray emission point and the center of the cephalostat. 


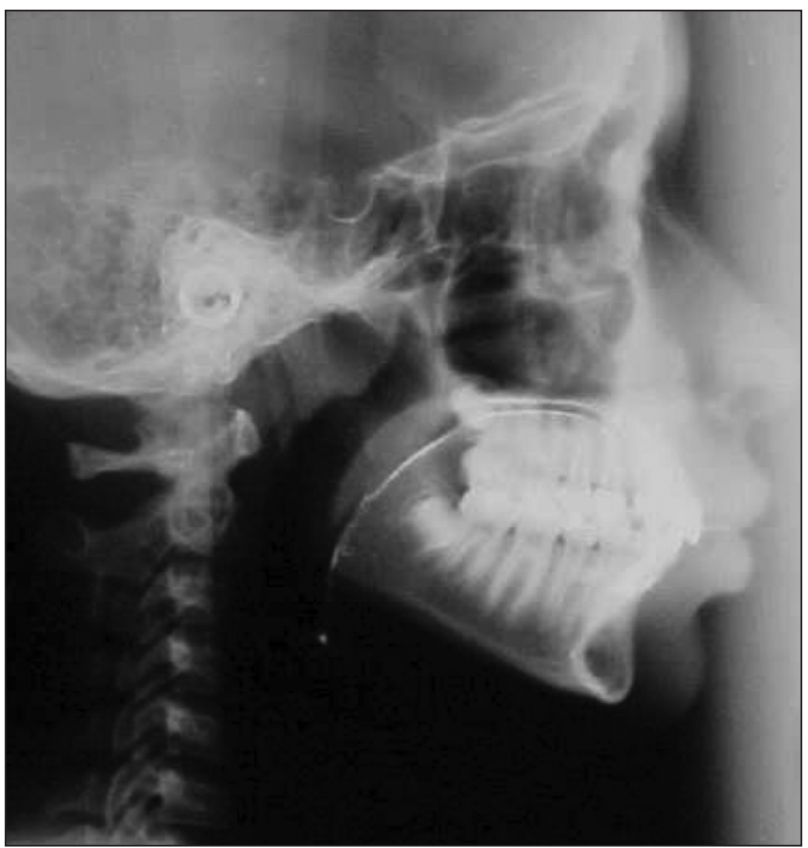

Fig 1. Lateral cephalometric radiography.

Cephalometric measurements and blinding procedure - The radiographs were handed over directly to the person in charge of the secretarial office of the research center, who blinded their identification by means of opaque labels. The radiographs were then stored in randomly numbered envelopes. After collecting population data, one of the authors (MLJ), who was unaware of whom the radiographs belonged to, traced the radiographs onto Ultraphan paper placed on top of a negatoscope. An anatomical drawing was produced and the linear measurements and angles (Fig 2) were traced out in order to determine the cephalometric variables (Table 1).

\section{Statistics}

The results relating to the variables from each patient were stored in an electronic spreadsheet (Microsoft Excel). The labels concealing the identities of the mouth breathing and nose breathing children were removed, and the two groups were regrouped irrespective of age or gender. Since the data showed Gaussian distribution, the mean, standard deviation and median were calculated. The cephalometry was compared between the mouth and nose breathing children (Table 2), and with the cephalometric pattern for apneic patients (Table 3) that has been widely described in the literature $e^{3,26,27}$. The oral and nasal cephalometric variables were compared using Student's t test, and the chi-square test was used for comparisons with the patterns in the literature.

\section{RESULTS}

Fifty-two of the 142 children were mouth breathers and 90 were nose breathers. The mean age ( \pm SD) was

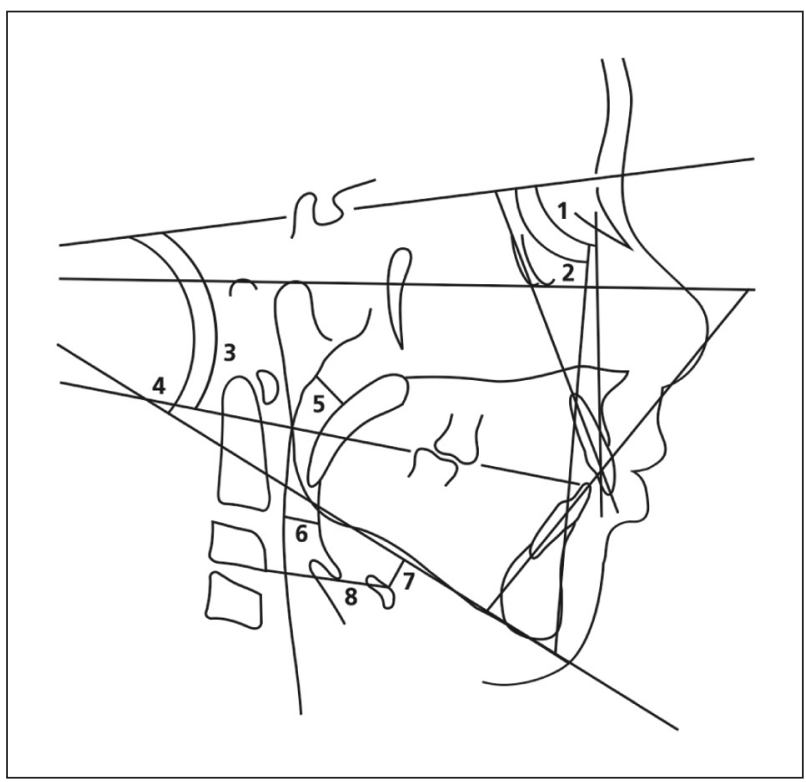

Fig 2. Anatomical drawing, linear measurements and angles traced out to determine the following cephalometric variables: 1: SNA; 2 : SNB; 3: NSPIO; 4: NSGoGn; 5: SPAS; 6: PAS; 7: MPH; 8: $\mathrm{C}_{3} \mathrm{H}$.

$124.8 \pm 24.8$ months for the mouth breathing children and 130.0 \pm 21.6 months for the nose breathing children $(p=0.31)$.

\section{Maxillomandibular variables}

The mouth breathing children showed a more retruded maxilla (SNA) and mandible (SNB) than nose breathing children did $(p<0.05)$ (Table 1). A higher proportion of the mouth breathing children presented measurements with the apneic pattern (Table 2), but this difference was not significant. However, the SNB angle tended to be $<78.74^{\circ}$ (apneic pattern) in the mouth breathing group $(p=0.056)$.

\section{Direction of mandibular growth and} inclination of the occlusal plane

The mouth breathing children presented greater inclination of the mandibular plane (NS.GoGn) and occlusal plane (NS.PIO) than nose breathing children did $(p<0.0001)$. Comparison of the two groups with the apneic pattern described in the literature showed that the inclinations of both the mandibular plane and the occlusal plane were comparable, with greater inclination observed for the mouth breathing group $(p<0.0005$ and $p<0.05$, respectively).

\section{Position of the incisors}

The upper incisors (1.NA) showed greater buccal inclination in mouth breathing children $(p<0.05)$. No difference in the inclination of the lower incisors (1.NB) was observed between the two groups, but the linear measure- 
Table 1. Normal cephalometric data for children $3,25,26,29$.

\begin{tabular}{|c|c|c|c|}
\hline $\begin{array}{l}\text { Cephalometric } \\
\text { parameters }\end{array}$ & Description & Diagnostic value & $\begin{array}{l}\text { Normal } \\
\text { value }\end{array}$ \\
\hline SNA & $\begin{array}{l}\text { angle formed by the sella-nasion line and line } \\
\mathrm{N} \text {-point } \mathrm{A}\end{array}$ & $\begin{array}{l}\text { anteroposterior position of the maxilla in rela- } \\
\text { tion to the skull base }\end{array}$ & $82^{\circ}$ \\
\hline SNB & $\begin{array}{l}\text { angle formed by the sella-nasion line and line } \\
\mathrm{N} \text {-point B }\end{array}$ & $\begin{array}{l}\text { anteroposterior position of the mandible in re- } \\
\text { lation to the skull base }\end{array}$ & $80^{\circ}$ \\
\hline ANB & differences between the SNA and SNB angles & the relation between maxilla and mandible & $2^{\circ}$ \\
\hline NS.PIO & $\begin{array}{l}\text { angle formed by the sella-nasion line and the } \\
\text { occlusal plane }\end{array}$ & $\begin{array}{l}\text { the inclination of the occlusal plane in relation } \\
\text { to the skull base }\end{array}$ & $14^{\circ}$ \\
\hline NS.GoGn & $\begin{array}{l}\text { angle formed by the sella-nasion line and man- } \\
\text { dibular plane }\end{array}$ & $\begin{array}{l}\text { the inclination of the mandibular plane in rela- } \\
\text { tion to the skull base }\end{array}$ & $36^{\circ}$ \\
\hline 1.NA & $\begin{array}{l}\text { angle of inclination of the upper incisor in rela- } \\
\text { tion to the NA line }\end{array}$ & $\begin{array}{l}\text { the extent of anterior inclination of the upper } \\
\text { incisor }\end{array}$ & $22^{\circ}$ \\
\hline $1-N A$ & $\begin{array}{l}\text { linear distance between the most salient point } \\
\text { of the buccal side of the upper incisor and the } \\
\text { NA line measured perpendicularly to the latter }\end{array}$ & $\begin{array}{l}\text { the extent of anterior inclination of the upper } \\
\text { incisor }\end{array}$ & $4 \mathrm{~mm}$ \\
\hline 1.NB & $\begin{array}{l}\text { angle of inclination of the lower incisor in rela- } \\
\text { tion to the NB line, which determines the extent } \\
\text { of anterior inclination of the lower incisor }\end{array}$ & $\begin{array}{l}\text { the extent of anterior inclination of the lower } \\
\text { incisor }\end{array}$ & $25^{\circ}$ \\
\hline $1-N B$ & $\begin{array}{l}\text { linear distance between the most salient point } \\
\text { of the buccal side of the lower incisor and the } \\
\text { NB line measured perpendicularly to the latter }\end{array}$ & $\begin{array}{l}\text { the extent of anterior inclination of the lower } \\
\text { incisor }\end{array}$ & $4 \mathrm{~mm}$ \\
\hline SPAS & $\begin{array}{l}\text { the thickness of the airway behind the soft pal- } \\
\text { ate along a line parallel to the Go-B point plane }{ }^{35}\end{array}$ & thickness of superior posterior airway space & $10 \mathrm{~mm}$ \\
\hline PAS & $\begin{array}{l}\text { linear distance between a point at the base of } \\
\text { the tongue and another point on the posterior } \\
\text { wall of the pharynx, both measured by the ex- } \\
\text { tension of a line from point } B \text { to point } \mathrm{Go}^{13}\end{array}$ & thickness of posterior airway space & $10 \mathrm{~mm}$ \\
\hline MP-H & $\begin{array}{l}\text { linear distance between } \mathrm{H} \text {, the most anterosupe- } \\
\text { rior point of the hyoid bone, and the mandibular } \\
\text { plane measured perpendicularly to the latter }\end{array}$ & $\begin{array}{l}\text { risk of occlusion, which increases directly with } \\
\text { the distance }\end{array}$ & $18 \mathrm{~mm}$ \\
\hline $\mathrm{C} 3-\mathrm{H}$ & $\begin{array}{l}\text { linear distance between } \mathrm{C} 3 \text { and } \mathrm{H} \text {, where } \mathrm{C} 3 \text { is } \\
\text { the most anteroinferior point of the third cer- } \\
\text { vical vertebra }{ }^{36}\end{array}$ & $\begin{array}{l}\text { risk of occlusion, which increases inversely with } \\
\text { the distance }\end{array}$ & $35 \mathrm{~mm}$ \\
\hline
\end{tabular}

Normal values from: Lowe $A^{3}$, Miles $\mathrm{PG}^{25}$, Guilleminault $\mathrm{C}^{26}$, Bibby $\mathrm{RE}^{29}$.

ments on the upper and lower incisors (1-NA and 1-NB) indicated a more anterior inclination in the mouth breathing children $(p<0.05)$. However, no differences in angular or linear measurements were observed between the mouth and nose breathing groups, compared with the apneic pattern.

\section{Pharyngeal air space}

The linear measurements relating to the nasopharyngeal air space (SPAS and PAS) were much smaller in the mouth breathing children than in the nose breathing group $(p<0.0001)$. Comparison with the apneic pattern showed that the mouth breathing children presented measurements that were very similar to those found in patients with OSAS $(p<0.0001$ and $p<0.01$, respectively).

\section{Position of the hyoid bone}

The vertebra-hyoid $\left(\mathrm{C}_{3}-\mathrm{H}\right)$ distance was longer in the mouth breathing children than in the nose breathing group $(p<0.05)$, whereas the distance between the hyoid bone and mandibular plane (MP-H) did not differ significantly between the two groups. Comparison of these variables between the two groups and with the adult apneic pattern showed shorter distances between the hyoid bone and both the $\mathrm{C}_{3}$ vertebra and the mandibular plane in the two groups of children, with no significant difference regarding the position of the hyoid bone. 
Table 2. Comparison of cephalometric data between the mouth and nose breathing groups.

\begin{tabular}{cccc}
\hline & Nose breathing & Mouth breathing & $\mathrm{P}$ \\
\hline SNA & $84.1 \pm 4.1$ & $82.6 \pm 3.8$ & 0.03 \\
SNB & $79.4 \pm 4.1$ & $77.5 \pm 3.6$ & 0.04 \\
ANB & $4.7 \pm 2.0$ & $5.1 \pm 2.3$ & 0.248 \\
NS.PIO & $18.1 \pm 4.4$ & $21.1 \pm 3.7$ & $<0.0001$ \\
NS.GoGn & $33.5 \pm 5.7$ & $38.3 \pm 5.2$ & $<0.0001$ \\
1.NA & $24.1 \pm 7.7$ & $26.3 \pm 6.2$ & 0.01 \\
1-NA & $4.5 \pm 1.9$ & $5.3 \pm 2.3$ & 0.04 \\
1.NB & $30.9 \pm 5.4$ & $31.8 \pm 5.8$ & 0.4 \\
1-NB & $6.4 \pm 2.3$ & $7.5 \pm 2.8$ & 0.02 \\
SPAS & $10.3 \pm 2.8$ & $4.9 \pm 1.9$ & $<0.0001$ \\
PAS & $12.3 \pm 3.1$ & $10.1 \pm 3.1$ & 0.0001 \\
MP-H & $11.3 \pm 5.2$ & $11.8 \pm 5.3$ & 0.06 \\
C $-H$ & $34.9 \pm 3.4$ & $33.6 \pm 3.2$ & 0.03 \\
\hline
\end{tabular}

\section{DISCUSSION}

The present study demonstrated that the cephalometry of mouth breathing children differs greatly from the measurements observed for nose breathing children, but is similar to the cephalometric pattern of patients with OSAS that has been described in the literature ${ }^{3,26,27}$.

The facial morphology of patients with obstructive sleep apnea has been determined on lateral cephalometric radiographs. However, few cephalometric studies on childhood OSAS are available in the literature.

The SNA and SNB angles, which evaluate the anteroposterior position of the maxillae and mandible, respectively, were smaller in the mouth breathing children. These data coincide with studies showing that mouth breathing reduces anterior maxillomandibular development ${ }^{14}$, such that these structures are more retruded in relation to the skull base. These findings were confirmed in the study by Kawashima et al. ${ }^{13}$, who found a retrognathic mandible in children in whom more than $75 \%$ of the palatine tonsils could be seen on clinical examination. Similarly, studies have shown equally retruded maxillae and mandibles in apneic patients ${ }^{3,25}$. This anatomical condition leads to a smaller oral cavity both in mouth breathing individuals and in apneic patients, with diminished functional space for the tongue, which will occupy a more posterior position, thus favoring obstruction of the upper airways during sleep.

The direction of mandibular growth and inclination of the occlusal plane, as given by the NS.GoGn and NS.PIO measurements, respectively, were greater in mouth breathing children. Nasal obstruction caused by tonsillar and adenoid hypertrophy impairs normal nose breathing. Such children will then adapt their respiration by moving over to mouth breathing through postural changes of the head ${ }^{28}$, maxillae, tongue and labial musculature, thereby altering the muscle pressure balance in the maxillae and teeth and modifying facial growth ${ }^{5}$. This process may explain the increased inclination of these measurements in mouth breathing children. The cephalometric pattern of patients with OSAS is also characterized by increases in these values, resulting in greater anterior facial height, clockwise growth of the mandible and a tendency towards open biting ${ }^{3}$. Lyberg et al. ${ }^{27}$ reported that the mandibular plane and the height of the anterior face were slightly greater in adults with OSAS. Their findings were similar to ours in children.

Greater inclination of the upper incisors (1.NA and 1-NA) was observed in the mouth breathing group. This finding can be explained by the pressure that the tongue

Table 3. Comparison of cephalometric data between the groups studied and the apneic pattern.

\begin{tabular}{ccccc}
\hline \multicolumn{2}{c}{ Apneic pattern* } & Nose breathing children (\%) & Mouth breathing children (\%) & P \\
\hline SNA & $<81.84$ & 25 & 39.21 & 0.112 \\
SNB & $<78.74^{\circ}$ & 44.56 & 62.74 & 0.056 \\
ANB & $>4^{\circ}$ & 52.17 & 64.70 & 0.203 \\
NS.PlO & $>14^{\circ}$ & 81.52 & 98.03 & 0.009 \\
NSGoGn & $>36^{\circ}$ & 23.91 & 60.78 & 0.00002 \\
1.NA & $>22^{\circ}$ & 56.52 & 72.54 & 0.086 \\
1-NA & $>4 \mathrm{~mm}$ & 40.21 & 56.86 & 0.082 \\
1.NB & $>25^{\circ}$ & 86.95 & 86.27 & 0.887 \\
1-NB & $>4 \mathrm{~mm}$ & 79.34 & 90.17 & 0.152 \\
SPAS & $<8 \mathrm{~mm}$ & 16.30 & 94.11 & 0.00000001 \\
PAS & $<11.88 \mathrm{~mm}$ & 36.95 & 60.78 & 0.010 \\
MP-H & $>17.75 \mathrm{~mm}$ & 13.04 & 11.76 & 0.966 \\
C $-\mathrm{H}$ & $<34.66 \mathrm{~mm}$ & 44.56 & 60.78 & 0.092 \\
\hline
\end{tabular}


exerts on the palatine side of these teeth, since many mouth breathing individuals have a retruded maxilla and mandible and the functional space for the tongue is therefore reduced. No increase in the 1.NB measurement was observed, probably because mouth breathers place the lip between the upper and lower incisors, because of the greater anterior inclination of the upper incisor. Through this, pressure is applied to the lower apical base, which leads to retroinclination of the lower incisors. No significant difference in these measurements was observed regarding the apneic pattern, although they tended to be higher in mouth breathing children.

The linear measurements of the nasopharyngeal air space (SPAS and PAS) were markedly reduced in the mouth breathing children, and this has also been observed in apneic patients ${ }^{6,27}$. The present study and other investigations $s^{3,5-7,70,13,14,23,25-27}$ have demonstrated the usefulness of cephalometry for diagnosing respiratory sleep disorders in children. Lymphoid tissue hypertrophy plays an important role in the physiopathology of these disorders in children and is the main target of therapeutic management. Guilleminault et al. ${ }^{26}$ suggested that maintaining nose breathing during childhood is important for preventing abnormalities of the facial skeleton.

In the present study, the MP-H measurement (which determines the distance between the hyoid bone and mandibular plane ${ }^{29}$ ) did not differ between mouth and nose breathing children, probably because this distance normally increases with age ${ }^{26}$. In children, obstruction of the airway is more common at the level of the nasophar$y n x$ and oropharynx, rather than in the musculature relating to the hyoid bone ${ }^{10,11}$ as observed in adult patients ${ }^{3,26}$. In the children studied here, the hyoid bone was still close to the mandibular plane, unlike in adults with OSAS ${ }^{3,26}$, in whom the hyoid bone is quite distant from the mandibular plane. On the other hand, the $\mathrm{C}_{3}-\mathrm{H}$ measurement was greater in the mouth breathing children because these patients extended their heads to improve their respiratory pattern, thus increasing cervical kyphosis ${ }^{28}$.

In conclusion, the present study demonstrated that mouth breathing children present abnormal cephalometric parameters, compared with nose breathing children, and that the craniofacial morphology of the former resembles that of patients with OSAS. This suggests that the apneic pattern develops early in the clinical history of patients with OSAS. Therefore, this deserves careful attention from all clinicians, particularly neurologists caring for children who are referred to them because of behavioral or learning problems.

\section{REFERENCES}

1. Remmers JE, DeGroot WJ, Sauerland EK, Anch AM. Pathogenesis of upper airway occlusion during sleep. J Appl Physiol 1978;44:931-938.
2. Budhijara R, Sharief I, Quan SF. Sleep disordered breathing and hypertension. J Clin Sleep Med 2005;1:401-404.

3. Lowe AA, Santamaria JD, Fleetham JA, Price C. Facial morphology and obstructive sleep apnea. Am J Orthod Dentofac Orthop 1986;90:484-491.

4. Redline S, Tishler PV, Tosteson TD, et al. The familial aggregation of obstructive sleep apnea. Am J Respir Crit Care Med 1995;151:682-687.

5. Zucconi M, Caprioglio A, Calori G, et al. Craniofacial modifications in children with habitual snoring and obstructive sleep apnoea: a casecontrol study. Eur Respir J 1999;13:411-417.

6. Miyao E, Miyao M, Ohta T, et al. Differential diagnosis of obstructive sleep apnea syndrome patients and snorers using cephalograms. Psychiatry Clin Neurosci 2000;54:659-664.

7. Özdemir H, Altin R, Sögüt A, et al. Craniofacial differences according to AHI scores of children with obstructive sleep apnoea syndrome: cephalometric study in 39 patients. Pediatr Radiol 2004;34:393-399.

8. Marcus CL. Sleep-disordered breathing in children. Am J Respir Care Med 2001;164:16-30

9. Scwab RJ. Genetic determinants of upper airway structures that predispose to obstructive sleep apnea. Respir Physiol Neurobiol 2005;147:289-298.

10. Di Francesco RC, Passerotii G, Paulucci B, Miniti A. Mouth breathing in children: different repercussions according to the diagnosis. Rev Bras Otorrinolaringol 2004;70:665-670.

11. Guilleminault C, Korobkin R, Winkle R. A review of 50 children with obstructive sleep apnea syndrome. Lung 1981;159:275-287.

12. Gozal D, O'Brien L, Row BW. Consequences of snoring and sleep disordered breathing in children. Pediatr Pulmonol 2004;26:166-168.

13. Kawashima S, Peltomäki T, Sakata H, Mori K, Happonen R-P, Rönning O. Craniofacial morphology in preschool children with sleeprelated breathing disorder and hypertrophy of tonsils. Acta Paediatr 2002;91:71-77.

14. Sousa JBR, Anselmo-Lima WT, Valera FCP, Gallego AJ, Matsumoto MAN. Cephalometric assessment of mandibular growth pattern in mouthbreathing children. Int J Pediatr Otorhinolaryngol 2005;69:311-317.

15. Marcus CL, Carroll JL, Koerner CB, Hamer A, Lutz J, Loughlin GM. Determinants of growth in children with the obstructive sleep apnea syndrome. J Pediatr 1994;125:556-562.

16. Crabtree VM, Vami J, Gozal D. Health-related quality of life and depressive symptoms in children with suspected sleep-disordered breathing. Sleep 2004;27:1131-1138

17. Carvalho LBC, Prado LBF, Silva L, et al. Cognitive dysfunction in children with sleep-disordered breathing. J Child Neurol 2005;20:400-404.

18. Carvalho LB, Prado LB, Silva L, et al. Cognitive dysfunction in children with sleep disorders. Arq Neuropsiquiatr 2004;62:212-216.

19. Moran CA, Carvalho LBC, Prado LF, Prado GF. Sleep disorders and starting time to school impair balance in 5-year-old children. Arq Neuropsiquiatr 2005;63:571-576

20. McLean HA, Urton AM, Driver HS, Tan Ak, Day Ag, Munt PW, Fitzpatrick MF. Effect of treating severe nasal obstruction on the severity of sleep apnoea. Eur Resp J 2005;25:521-527.

21. Peltomäki T. The effect of mode of breathing on craniofacial growth-revisited. Eur J Orthod 2007;29:426-429.

22. Oulis CJ, Vadiakas GP, Ekonomides J, Dratsa J. The effect of hypertrophic adenoids and tonsils on the development of posterior crossbite and oral habits. J Clin Pediatr Dent 1994;18:197-201.

23. Kawashima S, Niikini N, Chia-hung L, et al. Cephalometric comparisons of craniofacial and upper airway structures in young children with obstructive sleep apnea syndrome. Ear Nose Throat J 2000;79:499-506.

24. Fingeroth AI. Orthodontic-orthopedics as related to respiration and conductive hearing loss. J Clin Pediatr Dent 1991;15:83-89.

25. Miles PG, Vig PS, Weyant RJ, Forrest TD, Rochette Jr HE. Craniofacial structure and obstructive sleep apnea syndrome: a qualitative analysis and meta-analysis of the literature. Am J Orthod Dental Orthop 1996; 109:163-172.

26. Guilleminault C, Riley R, Powell N. Obstructive sleep apnea and abnormal cephalometric measurements. Chest 1984;86:793-794.

27. Lyberg T, Krogstad O, Djupeslandi G. Cephalometric analysis in patients with obstructive sleep apnoea syndrome. I. Skeletal morphology. J Laryngol Otol 1989;103:287-292.

28. Huggare JA, Laine-Alava T. Nasorespiratory function and head posture. Am J Orthod Dentofac Orthop 1997;112:507-511.

29. Bibby RE, Preston CB. The hyoid triangle. Am J Orthod 1981;80:92-97. 